\title{
TIEMPO Y CONTRATO. CRÍTICA DEL PACTO FÁUSTICO
}

François Ost

Facultés Universitaires Saint-Louis

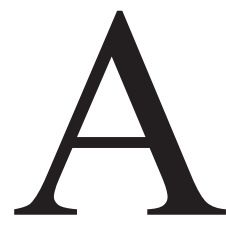

unque no haya sido frecuentemente señalado, el tiempo es, sin duda, el elemento decisivo de la economía contractual. El contrato es la anticipación de lo que vendrá, es el futuro irrevocablemente comprometido -en esto consiste su fuerza específica y también su función, particularmente económica. Sin embargo, es preciso que nos pongamos de acuerdo acerca de la naturaleza del tiempo así movilizado. Dos fábulas literarias -el mito de Fausto y la historia del mercader de Venecia- arrojan luz sobre una primera forma de temporalidad contractual: una forma que es al mismo tiempo instantaneista e inmutable y que conduce directamente a la destrucción de quienes se sirven de ella (apartado 1). En algunos aspectos, la teoría clásica de los contratos se inscribe dentro de esta perspectiva, formalista y voluntarista; la ficción literaria la artícula en sus extremos. Pero tanto las prácticas contractuales como ciertas innovaciones jurisprudenciales dejan entrever hoy otra temporalidad más continua, más flexible y más solidaria. Seguiremos sus meandros (apartado 2), no sin sugerir, en un tercer apartado, qué evoluciones similares se dibujan en el Derecho público, en el Derecho internacional y en el Derecho del trabajo. Por último, en un cuarto apartado, me ocuparé de proponer varios esquemas explicativos de las distintas evoluciones acaecidas: recurriré sucesivamente al análisis socio-jurídico de los contratos, a la teoría pragmática de la acción y a la teoría general del Derecho. Al tiempo del pacto fáustico, que termina, como Chronos, por devorar aquello que crea, espero poder oponer un tiempo neguentrópico, el de la alianza abierta y evolutiva entre compañeros; algo parecido a una buena fe compartida.

\section{1.- Fausto y Shylock, dos negaciones del tiempo}

Las diferentes versiones del mito de Fausto, desde el Faustbuch (o Volkbuch) de $1587^{1}$ hasta las lecturas contemporáneas, pasando por el Fausto

\footnotetext{
${ }^{1}$ Narración popular de Fausto: L'histoire du docteur Faust (1587) traducción de J. Lefebvre, Paris, Les Belles Lettres, 1970.
} 
de Marlowe (1590) y los de Goethe (1808 y 1832), nos muestran un viejo sabio que, decepcionado de la vida y ya de vuelta de todos los saberes, busca dominar las cosas y los seres; algo que, por cierto, se le presenta cada vez como algo más improbable. Confiando en que las prácticas de la magia le librarán de los límites materiales, se entrega a ellas: la magia es, en efecto, la abolición del tiempo y del espacio, una promesa de posesión inmediata, un poder transgresor ejercido sobre las cosas y los seres al que éstos parecen no oponer resistencia alguna. A las pacientes pesquisas del sabio, que debe arreglárselas con las leyes de la naturaleza para comprender sus secretos, la magia opone el milagro de una iluminación inmediata ${ }^{2}$. Fausto se ha vuelto impaciente: de la misma forma que no soporta la alteridad del objeto que desea, no soporta tampoco ya la dilación temporal. Además, es tanto lo que le fascina el cortocircuito mágico que cree que éste podría darle acceso inmediato a una posesión sin distancia -a un control sin alteración ni alteridad (ya sabemos cuán en el corazón de la magia está el principio de identidad, que funciona por imitación y por transmisión) ${ }^{3}$.

El otro reducido a sí mismo y el tiempo contraído dentro de un instante, esto es lo que, aunque en vano, el viejo sabio busca en la magia. Pero he aquí que, de repente, aparece el diablo y surge, entonces, la pregunta: ¿saciará Fausto su deseo cerrando el pacto con él? Aun sin alterar su identidad, el objeto del pacto difiere de una versión a otra del mito. En la narración popular (Faustbuch), lo que Fausto espera de Mefistófeles es que le enseñe y que le instruya en todas las cosas. A cambio de esto, le promete que al término del vigésimo cuarto año "podrá disponer de su cuerpo y de su alma, a su placer y por toda la eternidad"4. En el primer Faust de Goethe, el sabio busca "unirse" a Mefistófeles, busca identificarse totalmente con el espíritu de éste ("El espíritu que siempre niega") para tener, por fin, acceso a la verdadera vida, a la vida plena de la que el estudio de los libros le ha desviado. En las versiones posteriores del mito, el rejuvenecimiento obtenido por contrato es tema central; es, especialmente, el caso de la célebre opera de Gounod (1856) y también de Marguerite de la nuit (1925) de Pierre Mac Orlan, dónde a Fausto se le permite que durante sesenta años recobre la apariencia que tenía a los veinte.

Bajo estas diversas formas, lo que, sin embargo, sigue siendo el tema en cuestión es la ilimitación del deseo: deseo de saber, de juventud, de amor,

${ }^{2}$ A. Dabezies, Le mythe de Faust, Paris, Armand Colin, 1972, pág. 293.

${ }^{3}$ F. Mies, Faust ou l'Autre en question. Dieu, la femme, le mal, Namur, Presses universitaires de Namur, 1994, pág. 115.

${ }^{4}$ L'histoire du docteur Faust 1587, op. cit., pág. 79.

${ }^{5}$ Goethe, Faust, Paris, Librio, 1997, pág. 40. 
entendido en cada caso como un dominio sin obstáculos; dominio sin alteración ni alteridad. Un Fausto llevado a la posesión inmediata y perdurable del objeto intensamente deseado. En este sentido, se manifiesta muy significativa una cláusula del pacto inicial que aparece en el Récit populaire. Al entablar relación con el diablo, Fausto declara expresamente: "y para dar fe de ello, reniego de todos los seres vivos, de todas las cohortes celestiales y de todos los hombres". El pacto fáustico en su inmediatez y fusionalidad es el instrumento del solipsismo: hace aparecer un mundo sin más allá y sin profundidad (podríamos decir que es un mundo meramente aparente). ¿Qué temporalidad permite justificarlo? Goethe es muy explícito sobre este punto: es in situ que el Maligno le propone a Fausto que le pertenezca -"que así suceda al instante", le responde el sabio ${ }^{6}$. Y el pacto, una vez cerrado, surte efecto a partir de entonces y por toda "la eternidad". Inmediatez y eternidad colocan el compromiso en algún lugar fuera del tiempo que traduce bien el proyecto de dominio total que Fausto alberga: "iQue suene la hora, que caiga la aguja y que ya nunca más exista el tiempo para mí!”, exclama ${ }^{8}$.

A fin de cuentas, el tema del rejuvenecimiento no es más que una modalidad particular de esta negación del tiempo llevada a cabo mediante la técnica contractual y formalizada por la redacción de un escrito autentificado por una gota de sangre ${ }^{9}$-Goethe hace alusión a esto dos veces seguidas ${ }^{10}$, sin que el motivo sea aquí central, como sí lo es en las versiones posteriores. Lo importante es que, mediante el contrato, el otro se reduce a sí mismo (fusión mágica, identidad solipsista) y el tiempo se detiene - ¿acaso no se lamentaba Fausto ${ }^{11}$ de ver "todos sus sueños desvanecerse en el abismo del tiempo"?

A partir de entonces, ese tiempo del pacto fáustico es un tiempo cosificado: surge de la permanencia de lo mismo, más que de la creatividad histórica (o creatividad narrativa del yo expuesto al otro). La distinción señalada por Paul Ricoeur entre dos formas de identidad puede iluminar este punto: de un lado, la identidad como "mismidad" (el "idem" en latín y el "same" en inglés) que responde a la cuestión: “¿qué soy?"; de otro lado, la identidad como "ipseidad" (el "ipse" latín o el "self” inglés), que responde a la pregunta "¿quien soy?"12. Aun cuando descansa sobre la permanencia del "mismo"

${ }^{6}$ Ibidem, págs. 47 y 48.

${ }^{7}$ Ibidem, pág. 49.

${ }^{8}$ Ibidem, pág. 48.

${ }^{9}$ Ibidem, pág. 49.

${ }^{10} \mathrm{Ibidem}$, pág. 16 y 72: conducido al antro de la brujería, Fausto se pregunta: “¿Hay en esta cocina algún brebaje que pueda quitarme treinta años del cuerpo?"

${ }^{11}$ Ibidem, pág. 23.

${ }^{12}$ P. Ricoeur, Soi-même comme un autre, Paris, Ed. du Seuil, 1990, págs. 140-150. 
(algo que ponen de manifiesto particularmente los rasgos de carácter y las disposiciones adquiridas), el "yo" no sabría, sin alienación, reducirse a esa figura invariable de la mismidad. Le corresponde también existir, es decir, ser afectado por el tiempo que pasa y ser alterado por el comercio de otros -en pocas palabras, precisa comprometerse en una historia en la que uno es al mismo tiempo el actor y el paciente. Una historia que pone en acción los recursos éticos y jurídicos de la responsabilidad -entendiéndose ésta, precisamente, como la "respuesta" a la interpelación lanzada por el otro.

Sin lugar a dudas, el contrato es una modalidad muy eficaz de puesta en funcionamiento de esta responsabilidad: comprometiendo su palabra, el otro puede, a partir de entonces, "contar" conmigo, de suerte que me convierto para él en "alguien a quien se le puede exigir que rinda cuentas" de sus $\operatorname{actos}^{13}$. Sin embargo, aun es preciso que este contrato no aliene a sus protagonistas totalmente: pero ¿no es éste el sentido del compromiso de Fausto, cuando en su deseo de librarse de los límites de la realidad "vende su alma al diablo"? Esta es una opción a la vez instantánea e irrevocable que será ejecutada al pie de la letra: agarrándose a la mismidad que desea (y atrayendo al otro hacia ella, como Marguerite), Fausto se sustrae al tiempo que pasa (algo que simboliza el tema del rejuvenecimiento transitorio) alienando radicalmente, su ipseidad ${ }^{14}$. El contrato pasa de ser un instrumento natural de colaboración a convertirse en una maquina de alienación. Al cristalizar en su propio texto y negar el espíritu de confianza que debería inspirarlo, el pacto se inscribe fuera del tiempo, de la historia y de la narración -en tales condiciones no debe sorprendernos que llegue el momento de la destrucción (como decíamos antes: del daño). Y es que la inalteración sólo es posible en el fantasma: los signos de la juventud se transforman necesariamente, del mismo modo que el texto está siempre expuesto a las variaciones interpretativas de la historia compartida. Negarlo, encerrándose para ello en una pretensión de autonomía absoluta, es -paradójicamente- exponerse a la alienación más radical.

Si es cierto que la narración literaria es "un laboratorio de juicio moral"15 -y jurídico, añadiremos-, en el Mercader de Venecia de Shakespeare (1596)

\footnotetext{
${ }^{13}$ Vale la pena destacar en este sentido que Ricoeur utiliza precisamente el ejemplo de la promesa para ilustrar la especificidad de la identidad concebida como ipseidad. Por la "palabra dada" se instituye una permanencia en el tiempo de un tipo diferente a la simple persistencia de lo que queda (mismidad): cf. págs. 148-149.

${ }^{14}$ En este sentido, cf. F.Mies, Qui suis-je? Faust ou le refus de viellir, por aparecer; para una interpretación radicalmente diferente del Fausto de Goethe (comprendido esta vez como la aceptación de la finitud humana) véase L. Van Eynde, La libre raison du phénomène, por aparecer.
}

${ }^{15}$ P. Ricoeur, Soi-même comme un autre, op. cit., págs. 167. 
encontramos otra forma de experimento de pacto intemporal y diabólico. Al levantarse el telón, Antonio, rico mercader de Venecia, al igual que hacía Fausto, rumia su tristeza, decepcionado de la vida y ya de vuelta de todos los saberes. Pero, he aquí que aparece Basanio, un joven amigo sin dinero, que viene a pedirle la suma necesaria para cortejar a la bella Porcia, elegida de su corazón. Sucede, sin embargo, que Antonio está, de momento, totalmente desprovisto de una suma líquida de dinero puesto que toda su fortuna está invertida en varias operaciones marítimas en marcha. ¡Eso no habrá de suponer un problema!: pedirán el dinero a Shylock, usurero judío del foro; 3000 ducados que deberán ser devueltos tres meses más tarde. Antonio se ofrece como garante del acuerdo. Sin embargo, Shylock duda: Antonio es su enemigo jurado, alguien que -haciéndole de esta forma una peligrosa competencia- da y toma en préstamo sin intereses y que, además, en el pasado no dejó de "tratarle como a un perro". Dos hombres, de hecho, totalmente opuestos: el uno calculador, el otro generoso y hasta pródigo, el uno atesora y el otro gasta, Shylock levanta su fortuna sobre la razón y la posesión, el otro arriesga la suya en aventuras locas -y, además, es Shakespeare quien insiste: el primero es judío y el segundo cristiano. Aun así, Antonio no duda en tratar con Shylock, que es, por lo demás, "el diablo"16 -un diablo con quien, sin embargo, y como Fausto, él se dispone a llevar a cabo un contrato.

Pese a lo anterior, Shylock toma también su decisión: le presta los 3000 ducados y, además, lo hará sin intereses. Firmarán el pagaré inmediatamente, sin demora, ante notario. Sin embargo, "por puro placer", Shylock introduce una exigencia complementaria: "si la suma convenida no es reembolsada al final del plazo previsto, entonces tendrá derecho a una libra de carne de su deudor -de aquella parte del cuerpo que le plazca" ${ }^{17}$. Seguro del éxito de sus empresas, Antonio acepta tal clausula, suscribiendo con ella una caución que, como el Fausto de Goethe, viene acompañada de una apuesta potencialmente mortífera - y, así lo tenemos, comprometido en "cuerpo y bienes".

Cuando el plazo llega a su fin, vemos que los negocios de Antonio le llevan a la ruina: todas sus expediciones han fracasado, sus navegantes fueron hechos prisioneros por los piratas, se estrellaron contra las rocas o fueron arrastrados por las tempestades. Ahí lo tenemos, el día en cuestión incapaz de hacer honor a su deuda. ¿Deberá pagar su libra de carne? Shylock así lo exige: el pagaré clama en su favor y también el Derecho de la Ciudad de los Duques que él sabe invocar en su interés. ¿No descansa el crédito comercial de Venecia sobre el respeto absoluto a los compromisos contrac-

\footnotetext{
${ }^{16}$ Shakespeare, Le Marchand de Venise, traducción de Francois-Victor Hugo, Paris, Flamarion, 1997, pág. 35.

${ }^{17}$ Ibidem, pág. 37.
} 
tuales, comprendiendo aquí aquellos en los que los extranjeros son parte? ${ }^{18}$ Sin embargo, los amigos de Antonio se movilizan ofreciendo al prestamista hasta dos veces la cantidad de la suma garantizada. De nada sirve. Lo que reclama Shylock es la libra de carne: eso es lo que le pertenece; es su triunfo y su venganza. Así está escrito y así habrá de ser. ¿Acaso no ha sido el propio Antonio quien, por si sólo, irresponsable como de costumbre, ha forjado el instrumento de su propio suplicio? Como todos los parias, Shylock es de un legalismo puntilloso: apelar a la equidad de los jueces supondría que los magros privilegios que la ley le reserva pudieran verse disminuidos ${ }^{19}$. Habrá de ser el texto y nada más que el texto. El mismo duque apelará en vano a su clemencia -como ésta se articula en un registro metajurídico, no puede ser exigida. Al igual que el perdón o la gracia, la clemencia surge de la sobreabundancia del don, siendo así ¿cómo iba a dársela Shylock, si él únicamente cede para luego poder tomar más -él, el usurero a quien jamás una persona ha hecho un regalo?

En cualquier caso, Shylock se envuelve en la lógica de la venganza: lo más probable es que en ningún momento haya deseado ser reembolsado al final del plazo. Como pone de manifiesto su propia hija, es la "piel" de Antonio lo que él desea ${ }^{20}$ desde el principio -la venganza es su verdadera motivación ${ }^{21}$, una práctica del talión sobre la cual los judíos, por lo demás (como él, no sin razón, observa), nada tienen que aprender de los cristianos ${ }^{22}$. Nos daremos cuenta de que el tiempo de la venganza es un tiempo detenido e, incluso, regresivo; como si los relojes se hubieran detenido en el momento en el que se cometió la falta para la que se reclama castigo. El contrato es aquí el instrumento de ese tiempo detenido: lejos de evolucionar para procurar la colaboración de las partes, se paraliza en la ejecución mecánica de una venganza premeditada.

Pero, ¿permitiremos la ejecución de un contrato que es hasta tal punto inmoral? Mas que evocar algún instrumento legal que permita sin duda anular una cláusula penal aterradora -algo que no hubiera dejado de reducir la tensión dramática de la obra-, Shakespeare hace que la solución surja a partir de un exceso de legalismo. Disfrazada de joven jurista, Porfia, la mujer de Bassanio, es colocada junto al duque durante un simulacro de proceso en el que su erudición hará maravillas. En un primer momento, parece ser favorable a Shylock:

${ }^{18} \mathrm{Ibidem}$, pág. 75.

${ }^{19}$ En este sentido, cfr. R. Posner, Droit et littérature, traducción de Chr. Hivet y Ph. Jouary, Paris , P.U.F., 1996, pág. 114.

${ }^{20} \mathrm{Ibidem}$, pág. 73.

${ }^{21}$ Ibidem, pág. 63.

${ }^{22}$ Ibidem, pág. 64. 
efectivamente -dirá-, no es posible encontrar poder alguno en Venecia que pueda ir contra un compromiso formal ${ }^{23}$. Pero no por ello el usurero ha ganado su parte: lo que el pagaré establece es "una libra de carne", ni más ni menos -cualquier gota de sangre derramada o todo gramo de carne que exceda la cantidad establecida será considerada como una violación de las leyes de Venecia. ¡Qué número de teatro! He aquí a Shylock confundido, obligado a renunciar a su pagaré e, incluso, penalmente encausado por su condición de extranjero que ha amenazado la vida de un ciudadano de Venecia.

El drama aquí presentado a grandes rasgos es como, por lo demás, suele suceder frecuentemente en Shakespeare, al menos, ambiguo. Podemos ver tanto una obra antisemita, y no nos equivocaremos ${ }^{24}$ : el personaje de Shylock concentra todos los prejuicios vertidos sobre todos los de su pueblo, y la suerte final que se le reserva es injusta; aunque lo que Shakespeare pone en boca de aquel es una denuncia, a la que no le falta fuerza de convicción, de la hipocresía de la sociedad isabelina de su tiempo y, especialmente, de sus practicas esclavistas ${ }^{25}$. Como también podemos ver en esta obra una denuncia de la caricatura de contrato celebrado entre Shylock y Antonio, así como de la parodia de proceso en el que aparecen como partes contrarias. Es cierto que ningún sistema jurídico civilizado del siglo XVI hubiera prestado su apoyo a la ejecución de una cláusula sancionadora hasta tal punto contraria al orden público. Ya en esa época, el tribunal de equidad inglés libraba a los deudores de sanciones privadas desorbitadas; y, por lo que se refiere al Derecho judío, señala R. Drai ${ }^{26}$, siempre ha prohibido arrancar carne de un animal vivo y a fortiori de un hombre. Además, el proceso que se le hace a Shylock es una farsa jurídica: curioso proceso en verdad, sin juez, sin abogado, donde el amicus curiae (Porcia) que toma la decisión está directamente interesada en el asunto de la querella; los derechos de la parte acusada no son respetados y el desacuerdo civil se cierra con una sanción...penal. ${ }^{27}$

Podemos así entrever en el personaje de Antonio, como lo hace Jean Carbonier, el prototipo de capitán de industria, soberano y trágico en la línea de los Loewenstein y de los Kreuger destrozados por la depresión de la entreguerras ${ }^{28}$. En fin, es posible leer también en el drama-curiosamente

${ }^{23}$ Ibidem, pág. 90.

${ }^{24} \mathrm{Ph}$. Malaurie, Droit et literature, Paris, Editions Cujas, 1997; cf. también R. Drai, Le mythe de la loi du talion. Une introduction au droit hébraique, Paris, ed. Alinea, 1991, págs. 37-48.

${ }^{25}$ Shakespeare, Le marchan de Venise, op. cit., pág. 96.

${ }^{26}$ Op. cit., pág. 41.

${ }^{27} \mathrm{Ph}$. Malaurie, op.cit., pág. 72-73; R. Posner, op. cit., pág. 110; R. Drai, op. cit., pág. 47.

${ }^{28}$ J. Carbonnier, "Caractères juridiques", en Flexible droit, Paris, LGDJ, 8 éd., 1995, págs. 367-368. 
calificado de "comedia" -la fábula del talión; doble talión, en verdad: el que Shylock, el usurero caníbal, pretende ejercer en la persona de Antonio, y ese que Venecia decide, también ilegítimamente, imponer a Shylock ${ }^{29}$.

Por lo que se refiere a nosotros, concentraremos nuestra atención en la fuerza jurídica y la intangibilidad temporal del contrato. Fuerza jurídica que da miedo y que proviene del pagaré, cuya sola mención casi puede sesgar la vida de Antonio; todos estaban de acuerdo en esto, hasta el duque y el propio Antonio: nada ni nadie podía prevalecer frente al rigor de la cláusula escrita. $\mathrm{Y}$ es que un precedente de semejante laxitud hubiera podido poner en juego el mismo crédito del mercado de Venecia. La letra del pagaré contenía un futuro inexorable, que como hemos podido ver, arrancaba de un pasado de rencor, y cuyo presente no podía frustrar aquellas expectativas.

$\mathrm{Y}$, sin embargo, todos y cada uno de nosotros es consciente de la ilegitimidad de algo así: ¡summum ius, summa iniuria! ¿No sería entonces preciso padecer una "pequeña injusticia" (denunciar la letra del contrato) para evitar la comisión de una más grande? -pregunta Basanio ${ }^{30}$ ¿Es posible disociar en este momento la letra del espíritu del contrato? O, incluso más aun, ¿es tolerable que el espíritu que preside la conclusión y la ejecución del contrato esté en este momento sellado con la peor fe? Cuando imaginó la diabólica cláusula, Shylock no pretendía ser reembolsado y, una vez ganada su apuesta, no está dispuesto a hacer concesión alguna en su ejecución. La puesta en escena de estos interrogantes es lo que se propone la obra: aunque falten las palabras y los argumentos jurídicos, adivinamos que el contrato debe presentar una utilidad económica mínima para las dos partes y que debe descansar sobre un justo equilibrio para que el poder público concurra a su ejecución. ¿No se le ha propuesto a Shylock la devolución de su préstamo unido a copiosos intereses ( $; 400 \%$ !)? En estas condiciones, ¿no es abusiva y, finalmente, ilegal cualquier otra interpretación del contrato? La seguridad de la que se acompaña el contrato ¿debe entenderse como la inflexible ejecución de, incluso, sus cláusulas menos razonables? Sin embargo, ¿cómo dar cabida a la renegociación de sus términos si uno de los protagonistas se niega con obstinación?

Finalmente, la solución la encontraremos yéndonos a lo extremo, a una suerte de razonamiento al absurdo: poniendo la literalidad del contrato hasta su paroxismo, Porcia desencadena el drama y desenmascara la actitud de Shylock. Admitir la libra de carne y rechazar la sangre es demostrar mediante un argumento al absurdo que la cláusula o bien es inaplicable o es

\footnotetext{
${ }^{29}$ R. Drai, op. cit., págs. 37-48.

${ }^{30}$ Op. cit., pág. 90 .
} 
mortífera y que, en definitiva, se vuelve contra quien la invoca. Shylock, en efecto, sería un suicida si persiguiera hasta su fin la ejecución del contrato. Como Fausto antes, que intentaba asegurar su ipseidad vendiéndole su alma al diablo, Shylock se aliena en su obstinación al exigir la ejecución del pagaré. Está, en efecto, doblemente alienado: "loco" desde el momento en que rechaza todo arreglo aunque sea económicamente ventajoso, y más que nunca "extranjero" en la ciudad -judío y usurero para toda la eternidad; algo bien cierto, por cuanto que se ha creado para él un destino dónde los otros con agrado le empujarán. Aquí todavía, la mismidad de la letra (3000 ducados al final del término o una libra de carne) y el "carácter" (el judío no puede ser mas que usurero caníbal) encierran irrevocablemente la ipseidad de la persona, borrando el camino a toda temporalidad evolutiva, cerrando la puerta a toda renegociación de buena fe.

La lección sirve también para Antonio, cuya figura, si bien queda a la sombra de Shylock, no es por ello menos fascinante. Intriga la postura del magnífico armador que se vuelve de repente melancólico, tan dispuesto a suscribir una cláusula suicida, y que no discutirá su ejecución cuando los errores de cálculo acumulados hagan sonar la hora del fracaso. ¿Desesperanza real o desafío teatral a la manera veneciana? Poco importa, pues, en definitiva, lo que hace falta es terminar con esto; y así reclama que él y con él el contrato sean ejecutados - carne y letra confundidas como en la máquina infernal que escribía la sentencia sober el mismo cuerpo de los condenados en La Colonia penitenciaria imaginada por Kafka.

Solidarios en su suerte, Antonio y Shylock, Fausto y Mefistófeles hicieron del contrato una máquina infernal cuyos resortes, una vez sueltos no pueden ya ser rearmados -llega el plazo para la destrucción mientras que el tiempo se encierra en si mismo.

\section{2.- El tiempo contractual: del perfecto al imperfecto}

$\mathrm{Al}$ irse a lo extremo, las fábulas literarias de Fausto y Shylock constituyen una ilustración del tiempo contractual como tiempo a la vez instantáneo y fijo $\mathrm{y}$, en definitiva, intemporal privilegiado por la teoría clásica de los contratos. Sin embargo, las propias realidades del Derecho positivo han destruido hoy por mucho esta concepción.

Antes de llevar a cabo un análisis crítico de esta concepción clásica, conviene subrayar sus aciertos. En efecto, cuando reclamamos una temporalidad más evolutiva del vínculo contractual es preciso subrayar que el contrato es, antes que ninguna otra cosa, un instrumento de dominación del futuro, un instrumento de previsión destinado a reducir el componente azaroso del porvenir, los cambios de las circunstancias y las debilidades de la voluntad. Ser acreedor de un crédito que grava a otro implica algo así como 
si una parte del futuro pasara a ser, desde entonces, apropiable. Arrancado de las contingencias de los acontecimientos, sustraído a las fluctuaciones del plazo, el crédito representa la certitud de que lo convenido tendrá necesariamente lugar. Es como si, de repente, el porvenir se corporizara y se le atribuyera, bajo la forma de una anticipación segura de sí, consistencia normativa. Lo que está en juego es enorme. En el plano económico, la simple previsión de las ventajas que el futuro traerá, la perspectiva de los frutos que la cosa o la empresa engendrará representan un valor -un "interés" inmediatamente movible. Por la fuerza del performativo jurídico, estas prestaciones y ganancias, pese a serlo todavía "en potencia", se incorporan, desde entonces, al patrimonio del acreedor.

Por supuesto que en estas anticipaciones reside una parte del riesgo. Un futuro comprometido no es necesariamente un futuro garantizado. El riesgo contribuye incluso a la valorización de lo que está en juego. Precisamente, la regla del juego contractual es que los contratantes, o uno de los dos, asume esta parte de riesgo que inevitablemente conlleva el futuro. Esto es lo que implica adherirse al contrato y si a éste se le añade la cláusula "siempre y cuando el resto de las circunstancias permanezcan inalteradas", entonces la seguridad queda comprometida- contratar bajo esta condición es, por lo tanto, no comprometerse totalmente, pues, sin duda, es imposible tener en cuenta "todas las cosas" que pueden ser relevantes o medir rigurosamente en qué y hasta que punto permanecerán "iguales". Esto supondría también comprometerse en un proceso de renegociación permanente, surgido de una perspectiva que da valor a la seguridad, que pretende compensar el mínimo desequilibrio y detener el menor riesgo ${ }^{31}$.

Estas consideraciones, que insisten en una cierta fenomenología del contrato, siguen siendo correctas. Queda, sin embargo, por señalar que a esta confianza en las virtualidades del devenir (el "crédito de tiempo" que engendra el contrato), se une la confianza en el coparticipe del contrato. Más todavía: ésta condiciona aquella. He aquí lo que redescubren la doctrina y la práctica contemporáneas: el contrato no será un instrumento para dominar el futuro, no se le garantizará la estabilidad salvo a condición de mantener la confianza mutua sobre la que descansa. En tales condiciones, admitir que no se negocia mas que progresivamente y con prudencia, adaptarse, si se da el caso, a la renegociación de ciertas cláusulas -inscribirlo, para ser exhaustivos, dentro de una temporalidad móvil y evolutiva- no significa minar su fuerza performativa (es decir, su capacidad de engendrar el devenir del

${ }^{31}$ Cfr. A Seriaux, "Le futur contractuel", en Le droit et le futur, J.J. Austruy y otros, Paris, P.U.F., 1985, págs. 86-87. 
contrato), sino que, más bien al contrario, implica acercar a este último a sus condiciones de éxito.

Hechas estas precisiones, estamos ahora en disposición de presentar la teoría clásica de la temporalidad contractual y de demostrar las transformaciones que actualmente sufre, aun si, como lo subraya Thibierge-Guelfucci, la doctrina contemporánea ${ }^{32}$ no ha evolucionado operando un cambio de paradigma, sino mediante enmiendas y excepciones añadidas a unos dogmas que no han sido alterados.

Para la teoría clásica, las negociaciones precontractuales no tienen valor jurídico: todo sucede como si la autodeterminación de las partes hubiera tenido lugar en un instante de razón, aquel en el que sus consentimientos se encuentran y en el que el acto, que de la nada normativa ha pasado instantáneamente a la vida jurídica, fuera, a partir de entonces, perfecto y portador de todos sus efectos jurídicos futuros. Es la doctrina -según escribe J.M. Mousseron $^{33}$ - del "amor a primera vista", de "la unión espontánea e instantánea" de las dos voluntades; M.A. Frison-Roche apunta que aquí "el contrato es un punto en el tiempo donde la voluntad, viva como el relámpago, elige una voluntad alter ego dispuesta a ir a su reencuentro para un disfrute intemporal de su unión" 34 .

El acto, una vez formado, puede reivindicar su intangibilidad. Encerrado en la inmutabilidad de sus términos y en la supuesta "intención común de las partes", se encuentra ahí, seguro de atravesar el tiempo sin ser afectado ni por los cambios de las circunstancias, ni por las inflexiones internas de la mencionada voluntad. El contrato, una vez concluido, se impone a las partes escapando, en adelante, a su voluntad; resiste los impulsos de intervención por parte del juez, quien pudiera estar tentado de ajustar los términos; se opone con éxito incluso a una nueva ley que pudiera pretender ejercer una acción inmediata sobre sus efectos ya en curso. Tal "burbuja" o "bloque"35 se aísla del flujo del tiempo y se resiste a toda erosión, incluso lleva con él la supervivencia de la antigua ley bajo el título de elemento de las previsiones contractuales. "Burbuja" intemporal y "bloque" cristalizado de derechos y obligaciones. Cualesquiera que sean los desequilibrios que le afecten desde el origen o los que le imprimirán ulteriores sucesos, el contrato elude todo desa-

${ }^{32}$ C. Thibierge-Guelfucci, "Libres propos sur la transformation du Droit des contrats", en R.T.D. civ., abril-junio, pág. 370 y ss.

${ }_{33}$ J.M. Mousseron, "La durée dans la formation des contrats", en Études offertes à Alfred Jauffret, Aix-Marseille, Faculté de droit et de science politique, pág. 509.

${ }^{34}$ M.A. Frison-Roche, "Remarques sur la distinction de la volonté et du consentement en droits des contrats”, en R.T.D. civ., julio-septiembre, 1995, pág. 575.

${ }^{35}$ Estas expresiones son de C.Thieberge-Guelfucci, op.cit., pág. 360. 
fío ulterior. Excepto en la hipótesis extrema de fuerza mayor, que convierte en imposible la ejecución de las obligaciones, el contrato tiene vocación de ser aplicado, aunque haya devenido inútil o injusto en relación con los deudores. Sólo es preciso recordar en relación con esto los sorprendentes términos de la famosa sentencia "Canal de Craponne" en la cual el tribunal de casación no quiso consentir la revisión de una obligación de cantidad que resultaba de un acuerdo concluido... 316 años atrás: apoyándose sobre una concepción inflexible de la seguridad jurídica y una interpretación discutible del artículo 1134 del Código civil, el tribunal decidió que: “en ningún caso entraba dentro de la competencia de los tribunales ni de los jueces, por muy respetuosa con la equidad que les pareciera su decisión, tomar en consideración el tiempo y las circunstancias para modificar los acuerdos de las partes y sustituir por cláusulas nuevas las que fueron aceptadas libremente por los contratantes" ${ }^{\prime 36}$.

Ha sido denegada también la consideración de un tiempo transformador en decisiones más recientes, como es el caso de la sentencia del 31 de Mayo de 1988 en la cual el tribunal de casación sigue oponiéndose a la revisión del contrato por parte del juez: si las partes no han introducido una cláusula de adaptación con el fin de hacer variar el precio en función de las fechas del envío, es preciso presumir que su deseo era acogerse al precio inicial ${ }^{37}$.

Pero, como sucede en el caso de cualquier inhibición, el tiempo, desde luego, regresa; y es razonable pensar que con él más justicia y realismo. Para comenzar, por lo que se refiere a la conclusión del contrato, hoy estamos de regreso de la instantaneidad y, consecuentemente, a partir de ahora de lo que se trata es de la formación progresiva del acuerdo. La fase de negociación es hoy objeto de mayor atención: en estas negociaciones usualmente prolongadas en el tiempo y puntualizadas con acuerdos parciales, con promesas de adquisición de compromisos, con cartas de intenciones, descubrimos obligaciones específicas. Si bien no se trata todavía de ejecutar las cláusulas del contrato que tenemos entre manos, al menos nos comprometemos a negociar con lealtad, a no retirar la oferta de manera intempestiva y a esforzarnos por llegar a un acuerdo equitativo dentro de un plazo razonable. A propósito de estos "contratos de negociación" 38 se desarrolla una "deontología de la negociación" 39; deontología que tiene el mérito de insertar el futuro contrato

\footnotetext{
${ }^{36}$ Cass. fr., 6 de marzo 1876, D.P., 1876, I, pág. 193 y ss.

${ }^{37}$ Cass. fr., 31 Marzo 1988, Bull., civ. IV, n¹89, pág. 132.

${ }^{38}$ Cfr. B.Frydman, "Négociation ou marchandage? De 1'éthique de la discusión au droit de la négociation", en Droit négocié, droit imposé?, bajo la dir. de Ph. Gérard, F. Ost y M. van de Kerchove, Bruxelles, 1996, pág. 231 y ss.

${ }^{39}$ La expresión es de M. Fontaine, Droit des contrats internationaux. Analyse et rédaction des clauses, Feduci, Forum européen de la communication, 1989, pág. 34.
} 
en una perspectiva al tiempo más prolongada y más concreta: a la luz de las diferentes etapas de su génesis, el acuerdo no podrá ya ser interpretado ni ejecutado sólo bajo la luz de su letra o de una hipotética intención común puramente formal.

Si a partir de ahora la formación del contrato puede extenderse en el tiempo, su conclusión no se reduce ya más, ni ya necesariamente, a un instante puntual: bien los plazos para la reflexión retardan o suspenden la perfección del acto, bien la facultad de arrepentimiento o los plazos de retracción condicionan su mantenimiento ${ }^{40}$. El "flechazo" del amor ciego del que se trataba antes cede su lugar al consentimiento razonado y a la aproximación progresiva de los puntos de vista, más sólidos y realistas gracias a los ajustes graduales.

Por otro lado, ¿qué queda de la pretendida inmutabilidad del contrato? Desde el momento en que se le considera como un "vínculo" vivo entre las partes que une una "relación contractual", es previsible que nos adaptemos más fácilmente que ayer a un ajuste de sus términos en la medida en que una imperiosa necesidad lo justifique. Expuesto con más frecuencia que en el pasado al efecto inmediato de nuevas leyes ${ }^{41}$, el contrato ya no se encuentra tampoco al amparo de posibles intervenciones correctoras de los jueces preocupados por reequilibrar las prestaciones, por erradicar las cláusulas abusivas o por modificar los términos para tener en cuenta la delicada situación del deudor. Así la ley Neiertz del 31 de diciembre de 1989 autoriza al juez, si las dificultades que ha de afrontar el deudor lo justifican, a modificar los términos del contrato, sea que se trate de aplazar las devoluciones o de reducir las cantidades a pagar en concepto de intereses.

Esta mayor flexibilidad del contrato, lejos de poner de manifiesto su vulnerabilidad, le confiere una mayor capacidad de adaptación y, con ello, oportunidades más altas de sobrevivir a lo fortuito de las circunstancias. Da testimonio, concretamente, del hecho de que, a partir de ahora, en caso de irregularidad del acuerdo, será preferible la solución "regularizadora" que mantiene el contrato en vigor (esa que, por ejemplo, "tiene por no escrita" la cláusula ilegal), más que la sanción radical de la nulidad total ${ }^{42}$.

Sabemos también que el tribunal de casación acepta en adelante la fijación del precio por referencia a la tarifa del vendedor, a condición, sin

\footnotetext{
${ }^{40}$ J.-M. Mousseron, La durée dans la formation des contrats, págs 519 y ss.; cf. también J. Hauser, "Temps et liberté dans la théorie genérale de l'acte juridique", en Religión, société et politique. Mélanges en l'honneur de Jacques Ellul, Paris, 1983, pág. 503 y ss.

${ }^{41}$ H. Cousy, "Invloed van de nieuwe wet op lopende overeenkomsten", en De retroactiviteit van rechtsregels, Jura Falconi Libri, Leuven, 1998, págs. 39 y ss.

${ }^{42}$ C. Thibierge-Guelfucci, op. cit., págs. 362-363.
} 
embargo, de que este último no abuse de esa facultad ${ }^{43}$; algo que es mejor que la sanción radical, la antigua nulidad total y absoluta por indeterminación del precio.

Igualmente se privilegia el espíritu de colaboración entre las partes; una suerte de affectio contractus o voluntad de cooperar para lograr el éxito de una obra común, que implica el cuidado del mantenimiento del vínculo contractual y de su ejecución de buena fe. A partir de ahora podrán sancionarse aquellos comportamientos que sean desleales y la voluntad abusiva de ocultarse tras la letra para sustraerse a la obligación de renegociar el contrato que se ha convertido en insoportable para el deudor. De esta forma, el tribunal de apelaciones de París -no desaprobado por el de casación- puede condenar a una compañía petrolera por no haber cooperado con su distribuidor autorizado en la renegociación del precio de compra de carburantes, precio que no le dejaba ningún margen de beneficios a este último ${ }^{44}$ : incluso en caso de ausencia de cualquier cláusula contractual en este sentido, la buena fe obliga al acreedor a renegociar los términos del contrato por no presentar ya utilidad económica para la contraparte.

Para sintetizar la evolución sufrida, podríamos decir, con ThibiergeGuelfucci, que, de ahora en adelante, las relaciones entre libertad y seguridad se invierten ${ }^{45}$.

Expliquémoslo: en la teoría clásica, es la libertad la que está en su punto álgido justo antes de la conclusión del contrato, mientras que, a partir del instante en el que éste ha sido concluido, es la seguridad la que se maximiza -la ley contractual, irrevocable e intangible, impide en adelante liberarse de él. Es preciso ver además que, en este modelo, prevalece el punto de vista del más fuerte: libre a la hora de decidir entrar o no en el contrato, libre de escoger quiénes serán las otras partes contractuales y de fijar los términos del contrato en cuestión; el contratante más fuerte se beneficia entonces de una "seguridad jurídica" que podría muy bien significar inseguridad e injusticia para el deudor poco afortunado. Esta situación se invierte hoy, la libertad contractual se limita en el momento de la conclusión del acuerdo (toda suerte de obligaciones canalizan su negociación y orientan el contenido de sus cláusulas), mientras que, por el contrario, aumenta la posibilidad de salir del contrato o, al menos, de obtener una relajación de sus términos. Actualmente, todo tiene lugar como si a una fase preliminar más "aseguradora" le sucediera una fase de ejecución más "liberadora": y es que, sobre todo,

${ }^{43}$ Cass., Ass. Plén. 1 diciembre 1995, D, 1996, pág. 13, concl. Jéol y nota L. Aynes; RTD civ., 1996, pág. 153, obs. Mestre; J.C.P., 1993, II, 22565 y nota J. Ghestin.

${ }^{44}$ Cass., Com. 3 noviembre 1992, J.C.P., 1993, II, 22164 y obs. Virassamy.

${ }^{45}$ Op. cit., págs. 375-376. 
prevalece el cuidado en la protección del más débil, que tiene necesidad de ser debidamente informado antes de vincularse y que, en lo que sigue, debe poder beneficiarse de un compromiso que mantenga una justa contraparte y un efecto útil para él.

Para la concepción clásica, el contrato hacía surgir instantaneidad de su conclusión e inmutabilidad de su ejecución: la intangibilidad de la letra acompañaba la espontaneidad casi mágica de su escritura. De hecho, un contrato así se situaba "fuera del tiempo". Los desarrollos contemporaneos, restituyéndo al contrato la duración de la vida concreta, han hecho que éste reencuentre el hilo del tiempo y esto es así tanto antes como después de su conclusión. La inmutabilidad de la letra hace así lugar a la progresividad del espíritu: el contrato es un vínculo con vida que va escribiéndose a lo largo de sus distintas etapas de elaboración. Del contrato tal y como fue expresado al contrato querido o deliberado, y del contrato concluido al contrato ejecutado, se producen una buena cantidad de metamorfosis en el curso de las cuales se ejerce la fuerza consolidativa (pero a veces también destructiva) del tiempo: es el pasaje progresivo de lo posible a lo real, de lo indeterminado a lo determinado, de lo informe a lo formado y de la potencia al acto. Pero el acto jurídico que resulta no puede pretender su perfección el día de su conclusión formal. La teoría clásica veía perfecto este acto a partir del simple hecho de la concordancia de las voluntades del que era resultado. Su "intemporalidad" era el tiempo ficticio y abstracto del perfecto que presenta al acto o a la acción en un estado (siempre ya) alcanzado, como si el dominio que la voluntad ejerce sobre el tiempo fuera tal que ella, desde el principio, detuviera por completo los avatares. Podríamos decir, por otro lado, que el tiempo contractual que se manifiesta hoy a través de sus transformaciones jurisprudenciales y legislativas es más bien el tiempo del imperfecto -tiempo que dura y que es iterativo, que presenta la acción siempre desenvolviéndose y cuyo comienzo y final no son identificables con precisión. Lejos de traducir la imperfección del contrato, este imperfecto da testimonio más bien de su mayor capacidad de supervivencia al satisfacer mejor que ayer las exigencias de justicia y de utilidad económica.

Claro que esta transformación del tiempo contractual no es ajena a la modificación de la concepción acerca de los fundamentos del contrato. El "perfecto" del contrato instantáneo e inmutable va de la mano de la sobrevaloración, típicamente liberal, de la autonomía de la voluntad: una vez ha encadenado al tiempo, la voluntad de las partes debe también tener fuerza de ley sobre ellas. Con el tiempo del imperfecto, el centro de gravedad del contrato se desplaza, y no es tanto, como un modo de pensar dicotómico nos conduce a menudo a pensar, en dirección hacia un orden público rígido (en última instancia, solamente habríamos sustituido una soberanía por otra, la 
perfección de la voluntad estática ocuparía el lugar que fue dejado libre por las partes), que en dirección a los elementos más objetivos, más realistas y más institucionales de la relación contractual: dicho en dos palabras, "lo útil y lo justo"; para hablar como J. Ghestin: "el fundamento de la fuerza vinculante reconocida al contrato por el Derecho objetivo se deduce de su utilidad social y de su conformidad con la justicia contractual" ${ }^{16}$.

J. Carbonnier había anticipado el cambio: él anunció que la mayor atención que venía prestándose a los elementos realistas del contrato iba a desplazar progresivamente el centro de gravedad del contrato del momento de su formación al de su ejecución ${ }^{47}$. A partir de entonces es menos la voluntad autónoma la que cuenta -aunque ésta sigue siendo el ideal del contrato y el elemento que da inicio a la constitución de un vínculo durable-, que la puesta en funcionamiento de una institución inspirada por las ideas de buena fe, de equilibrio contractual y de utilidad económica. Esa inconclusión de la que el imperfecto del contrato da testimonio llama a una elaboración progresiva de sus previsiones y, si se da el caso, a un ajuste de sus términos. Los nuevos principios, surgidos menos de un "dirigismo" que de un "objetivismo" contractual ${ }^{48}$, contribuyen a partir de ahora a darle forma. En primer lugar, se pensará en la búsqueda de la igualdad subjetiva entre las partes que explica que las obligaciones de información y de lealtad sean a cargo del vendedor y que justifica la interpretación extensiva de los vicios de consentimiento o, más aun, la interpretación de las cláusulas, en Derecho de consumo, en el sentido más favorable al consumidor. A continuación se citará el principio de equilibrio contractual, entendido esta vez en sentido objetivo, principio que permite al juez remodelar el acuerdo que hubiera introducido obligaciones desproporcionadas a cargo de una de las partes y que, desde el momento en que remedia desequilibrios iniciales tales como las cláusulas penales manifiestamente injustas y los desequilibrios que tienen lugar posteriormente, justifica aquello que permita entreabrir la puerta a la revisión por imprevisión. Evocaremos, por último, un nuevo principio de "fraternidad contractual" que implica que cada uno debe "tener en cuenta, más allá de sus propios intereses, el interés del contrato y el de la otra parte contratante, aceptando ciertos sacrificios con el fin de favorecer la conclusión, la ejecución y el mantenimiento del contrato entendido como fundamento de una colaboración" ${ }^{\prime 4}$. En virtud de este principio (que quizá prefiramos reconducir al de buena fe), en ocasiones, como ya lo hemos vis-

\footnotetext{
${ }^{46}$ J. Ghestin, "La notion de contrat”, en Recueil Dalloz, 1990, Chronique XXV, pág. 149.

${ }^{47}$ J. Carbonnier, "Sociologie de la vente", en Flexible droit, op. cit., pág. 577.

${ }^{48}$ La distinción es de M.A. Frison-Roche, op. cit., pág. 577.

${ }^{49}$ C. Thibierge-Guelfucci, op.cit. pág. 382.
} 
to, se grava a las partes con una obligación de renegociación con el fin de asegurar la continuación de sus relaciones contractuales.

¿Diremos que esta concepción es decididamente demasiado idealista y que la fraternidad se inscribe más allá del Derecho? ¿Preferiremos partir de una antropología más pesimista y no ver entre los co-contratantes más que a dos enemigos con intereses opuestos que buscan solamente maximizar sus respectivas posiciones? Esta es la postura adoptada por Frison-Roche, pero es muy significativo el que esta autora, a partir de ese punto de comienzo opuesto, llegue a una misma concepción del contrato "que se extiende en el tiempo": "mecanismo sospechoso, industrioso, tentativo y prudente [el acuerdo] es el instrumento pesimista de esta guerra fría, conflicto creador sobre el que se construye el contrato" -un contrato "que se extiende en el tiempo y que va a convertir en obsesivas las cuestiones acerca de los procedimientos y las pruebas" ${ }^{\circ 0}$.

Concluyamos: aspirando a encerrarse en el "perfecto" del acto jurídico, el contrato clásico creía beneficiarse de una "mismidad" intangible -sucediera lo que sucediera, tal contrato se "mantendría". Pero esto suponía despreciar la finitud de todos nuestros proyectos, negar la falta de completitud de nuestras previsiones y la indeterminación de nuestras intenciones, ocultar las inevitables contingencias de los acontecimientos por venir. Y así, aferrándose a la letra del acuerdo, corría el riesgo de ahogar el espíritu de colaboración sobre el que descansaba. Al restablecer el imperfecto de la duración concreta, la concepción moderna del contrato da oportunidad a su ipseidad -esto es, a su capacidad de permanecer el mismo, al tiempo que se reinventa a si mismo de otro modo, cada vez que las circunstancias lo exigen.

\section{3.- Contrato social, tratado internacional, contrato de trabajo...}

Los análisis en los que nos hemos sumergido no son solamente la panacea del Derecho privado: en otros sectores jurídicos aparecen también confirmados. La cuestión del contrato social, fundamento del edificio político-jurídico moderno, nos ofrece una primera ilustración particularmente significativa. En el espíritu de los "padres fundadores" (Hobbes, Locke, Rousseau), el contrato social es caracterizado, siguiendo el ejemplo del contrato privado, por la instantaneidad de su conclusión y la intangibilidad de su ejecución.

Para Hobbes, por ejemplo, el fin del estado de naturaleza y el traspaso del poder absoluto por parte del pueblo al Leviatán tiene lugar en un instante

\footnotetext{
${ }^{50}$ M.A. Frison-Roche, op.cit., pág. 575.
} 
de razón y no viene acompañado de ninguna especie de deliberación ni entre los ciudadanos, ni con el designado como soberano, hacia quien, a partir de entonces, todos manifestarán respeto ${ }^{51}$. Como en un registro mágico, es "instantáneamente" como se produce el efecto prodigioso: uno se vincula y, al segundo mismo, bajo la sombra del soberano todo poderoso, se vuelve imposible retornar a las condiciones iniciales. "Corto-circuito" político por el cual el pueblo, tan pronto se constituye en actor político, se auto-anula entregando totalmente su lealtad al poder absoluto del gran autómata político. El poder confiado al Leviatán es perpetuo, desde el momento en que el compromiso que lo produce es, el mismo, irrevocable: desde ese preciso momento nos encontramos sin la menor posibilidad de revisión de los términos del contrato. Al poder se le asegura una "eternidad de vida artificial" (es decir: "institucional") y ello a la vista de una "seguridad perpetua" ${ }^{52}$ : de hecho el pueblo, temeroso y alienado por el contrato y bajo el liderazgo del gran Leviatán, busca la seguridad. Trocando su libertad por una pretendida seguridad, el pueblo se encierra en una intemporalidad que lo convierte, a partir de ese momento, en un extraño a si mismo (de nuevo la dialéctica de la mismidad y la ipseidad).

También para Locke y para Rousseau es de manera instantánea como se opera por medio del contrato social el pasaje del estado de naturaleza al estado social. Locke: "Cuando, nombrando a cualquiera de entre ellos, los hombres deciden constituir una única comunidad, tal acto tiene como efecto asociarlos de forma instantánea $\mathrm{y}$, a partir de entonces, forman un cuerpo político único"53. Rousseau: "En el instante y en lugar de la persona particular de cada contratante, este acto de asociación produce un cuerpo moral y colectivo" 54 . Esta forma de contracción del tiempo no deja de suscitar, sin embargo, un problema que no pasa desapercibido a Rousseau: ¿cómo concebir que en un instante tan breve la voluntad general que se forma pueda determinarse eligiendo sus instituciones a la luz de la razón? El problema es formulado de esta forma: "Para que un pueblo que nace pueda probar las sanas máximas de la política y seguir las reglas fundamentales de la razón de Estado, haría falta que el efecto pudiera devenir causa, que el espíritu social que debe ser la obra de la institución presida la institución misma y

${ }^{51}$ Th. Hobbes, Léviathan, traducción al francés de F. Tricaud, Paris, Sirey, 1971, p. 177; cf. También S. Goyard-Fabre, Le droit et la loi dans la philosophie de Thomas Hobbes, Paris, Klincksieck, 1975, pág. 116.

52 Th. Hobbes, Leviatán, op. cit., pág. 202.

${ }_{53}$ J. Locke, Deuxième traité du gouvernement civil, trad. al francés por B. Wilson, París, 1977, p. 129.

${ }^{54}$ J.-J. Rousseau, Du contrat social. Ou principes du Droit politique, Paris, Bordas, 1972, pág. 76. 
que, ya antes de las leyes, los hombres fueran quienes deben llegar a ser por ellas" ${ }^{55}$. Será preciso entonces que por algún proceso de conversión íntima o de iluminación colectiva, los individuos y el pueblo se anticipen de cierta forma al efecto pedagógico previsto por las leyes y al fluir del tiempo.

De la misma manera, Rousseau desconfía de la deliberación política en cuanto que, al estar frecuentemente asimilada a la promoción de los intereses partisanos, podría minar las instituciones poniéndolas bajo el efecto de las "asociaciones particulares": así, el "nudo social comienza a relajarse (...), las pequeñas sociedades influyen sobre la grande, el interés común se altera, la unanimidad no reina más en las voces y surgen contradicciones y debates" ${ }^{56}$. ¿Cómo podemos entonces apartar el espectro de la división social y restaurar la "unanimidad" necesaria para la fundación sagrada de la política? Conocemos las recetas imaginadas por Rousseau: las leyes escritas por un legislador inspirado y, para ser exhaustivos, supra-humano ("los dioses serÍlan necesarios para darles leyes a los hombres" ${ }^{\prime 57}$ ), el recurso a los resortes de la religión civil y a las virtudes del juramento y después, especialmente, -en un sorprendente regreso de lo reprimido- la atención extrema dada por el legislador a las mores, a las costumbres y a las tradiciones que hacen la vida real de los pueblos, marcan el corazón de los ciudadanos y son "la verdadera constitución del Estado" 58 . El gran legislador no deja de interesarse por estas tradiciones, reflejo de un tiempo prolongado, evolutivo y colectivo que desborda por todos lados el tiempo instantáneo del contrato social. De hecho, escribe Rousseau, "aunque parece contentarse con reglamentos particulares, en secreto se ocupa de aquel"59. Y, en efecto, hace bien ocupándose de ello: la opinión, las mores, las costumbres vienen a formar el espíritu de las leyes; suplen sus inevitables carencias y mantienen el vínculo social aun si se relajan; al sustituir el hábito por la autoridad, permiten también economizar la fuerza.

En principio pues el contrato social estaba entonces concebido en la misma línea instantánea e inmutable en la que era concebido el contrato civil; de esto se seguía una concepción formal y positivista de la Constitución (y, más generalmente, de la producción de las leyes); sólo la letra de ésta, expresión de la voluntad soberana de la nación, era autoridad -habiendo sido inspirada y guiada su interpretación por los valores y principios, y estando su ejecución ulterior constreñida en los márgenes del Derecho; como, por lo demás,

\footnotetext{
${ }^{55}$ Ibidem, págs. 109-110.

${ }^{56}$ Ibidem, pág. 182.

${ }^{57}$ Ibidem, pág. 107.

${ }^{58}$ Ibidem, pág. 126.

${ }^{59}$ Ibidem, pág. 126.
} 
el tiempo prolongado sobre cuyo fondo había tenido lugar su edicción. Pero Rousseau había anticipado bien el problema: privada de este cemento de valores y de principios, separada de la duración real y evolutiva de la historia, encerrada en el perfecto de su letra y sorda a las transformaciones de su espíritu, la ley no podría responder a esas expectativas. De la misma manera, nos hemos aproximado progresivamente a una concepción más material de la Constitución y de la ley, algo que es también una forma de volver a tomar el tiempo continuo y evolutivo del imperfecto ${ }^{60}$. Un Derecho pre $\mathrm{y}$ trans-constitucional ha pasado a asegurar las transiciones y enmarca las revisiones constitucionales, determinados principios supra-constitucionales son liberados y algunas normas fundadoras son puestas al abrigo de revisiones constitucionales intempestivas, tribunales constitucionales aseguran de un día para otro la actualización de la ley fundamental, en Estrasburgo, una Corte supranacional recuerda a los Estados europeos la prioridad de los derechos fundamentales sobre la razón de Estado. Tantas instituciones y técnicas destinadas a delimitar las soberanías nacionales, a relativizar el voluntarismo de las leyes subordinándolo al respeto de los principios superiores y asegurándoles una puesta en funcionamiento evolutiva conforme con los movimientos largos y profundos de la conciencia colectiva.

Una rápida incursión en el dominio del Derecho internacional público debería convencernos de que los tratados internacionales, que son contratos entre Estados, no son tampoco ajenos a la evolución de la que aquí nos ocupamos. Cualquiera que haya podido ser la concepción voluntarista-formalista que prevaleció todavía ayer en relación con ellos, hoy predomina una aproximación realista en cuyo centro figura la noción de buena fe. "Todo tratado debe ser ejecutado de buena fe" establece el artículo 26 de la Convención de Viena sobre el Derecho de los tratados (1969). Es igualmente de "buena fe" como ha de ser interpretado el tratado (artículo 31). De estas exigencias, el Tribunal Internacional de Justicia de La Haya deduce una obligación de renegociar el tratado (más que establecer su ruptura) cuando las circunstancias han modificado los elementos de éste. Tal fue la decisión tomada el 25 de Septiembre de 1997 en el marco de un litigio entre Hungría y Eslovaquia. Veinte años antes los dos Estados habían concluido un tratado con el fin de realizar en común unos trabajos faraónicos de acondicionamiento y desarrollo de la zona del Danubio: estaba prevista una inmensa central hidroeléctrica, así como unas barreras, lagos artificiales, un sistema de canales y de esclusas. Sin embargo, pronto se acumularon las dificultades:

\footnotetext{
${ }^{60}$ Cfr. Particularmente O. Beaud, La puissance de l'Etat, P.U.F., París, 1994; La democratie continue, bajo la dirección de D. Rousseau, París, LGDJ, 1995; F. Ost, Le glaive et le sablier. Donner le temps, dire le droit, por aparecer.
} 
problemas financieros y, también, ecológicos. Los trabajos se ralentizaron y en 1989 Hungría suspendió su participación en el proyecto: entonces, la liberalización política en curso permitió a los científicos y a los defensores del medio ambiente expresar sus miedos en relación con los daños causados al medio natural. Sin embargo, Eslovaquia persiste: construye en su territorio una central de dimensiones más reducidas y para alimentarla desvía no menos de nueva décimas partes del volumen de las aguas del Danubio.

El Tribunal entenderá que tal desvío, que implica un perjuicio grave para el medio ambiente de Hungría, es ilícito, pero, con todo, no accede a la petición de ésta, que entendía que el tratado debía romperse. Lo que dice el Tribunal es que el acuerdo, que sigue vinculando a las partes, contiene dispositivos evolutivos susceptibles de completar las normas medioambientales más recientes. Lejos de ser rígido, el tratado prevé una obligación continúa y por tanto evolutiva de velar por la calidad de las aguas del Danubio y por la protección del medio ambiente. Los dos Estados son entonces reenviados a la mesa de renegociación con la obligación de cooperar "de buena fe": ha de intentarse hacer prevalecer el espíritu del tratado sobre la letra. "El principio de buena fe", concluye el Tribunal, "obliga a las partes a aplicar el acuerdo de forma razonable, de tal forma que su objetivo, comprendiendo el respeto hacia el medio ambiente, pueda ser alcanzado" ${ }^{\text {. }}$.

El Derecho del trabajo nos provee un tercer terreno privilegiado de observación de la superación de la concepción intemporal e individualista del contrato. ¿Acaso no habla Alain Supiot del contrato de trabajo como de "una síntesis original de los conceptos de estatuto y contrato"62? Estas dos categorías -nos explica-, una de las cuales postula y la otra excluye la voluntad de los sujetos de derecho, han sido "reelaboradas para responder a las cuestiones planteadas por la relación de trabajo"63.

Al comienzo, sin embargo, es decir, en el Código civil de 1804, no se trataba de una relación laboral, sino del trabajo-mercancia negociado por el trabajador en los términos de un contrato de prestación de servicios, asimilado al contrato de arrendamiento de cosas. Es tan poco lo que se distingue esta forma de arrendamiento del arrendamiento de mercancías que sólo dos artículos del Código (el artículo 1780 y el 1781) le han sido consagrados. Dentro de la perspectiva liberal de la época, el trabajador-persona, sujeto de derecho, dotado de autonomía, se vincula libremente con el empleador en una relación supuestamente equitativa; le arrienda su fuerza de trabajo, el

${ }^{61}$ Tribunal internacional de Justicia, sentencia de 25 de Septiembre de 1997 en el asunto relativo al projecto Gabcokovo- Nagynaros (Hungría-Eslovaquia), párrafo 141-142.

${ }^{62}$ A. Supiot, Critique du Droit du travail, París, P.U.F., 1994, pág. 13.

${ }^{63}$ Ibidem, lo subrayo. 
trabajo-mercancia es asimilada a un elemento de su patrimonio. La contradicción fundamental sobre la cual descansan estas calificaciones jurídicas es que a pesar del mutismo de la legislación, el verdadero objeto del contrato no es otra cosa que el cuerpo del trabajador -un cuerpo sobre el cual ejerce su ascendencia el empleador.

Ahora bien -no cesamos, por otro lado, de afirmarlo- el cuerpo humano está, en principio, fuera del comercio. ¿Cómo conciliar entonces la validez del contrato de trabajo con la ilegalidad de las convenciones que tienen el cuerpo como objeto? Hace falta superar esta contradicción pues la cosificación de la persona avanza amenazante.

La alineación de la que los trabajadores, comprendiendo aquí también a los niños, fueron víctimas en el siglo XIX es, por lo demás, una ilustración histórica indiscutible.

No estamos pues tan lejos entonces de la libra de carne comprometida en garantía por Antonio o de la cesión de toda su persona, cuerpo y alma, de Fausto a Mefistófeles. En el molde del contrato individualista-instantaneista, el trabajo-objeto recobra y arrastra al trabajador-persona. En nuestra lengua, diremos que la "mismidad" del trabajo-mercancía o del cuerpo alienado encierra la "ipseidad" del trabajador. A expensas de empleos precarios, condenado a ganar su vida "día a día", privado de todo estatus y de toda estabilidad permanente, el trabajador es llevado a la condición de cosa afectada en virtud de los impulsos del contrato -empleado un día, y arrojado, al día siguiente, a una situación de no derecho.

El progreso llegará de la mano de la emergencia progresiva, a lo largo del s.XX, de un Derecho del trabajo que pondrá su empeño en reinsertar los valores extra-patrimoniales del trabajador-persona en la relación mercantil sobre el trabajo-cosa. Para empezar dejará de ignorarse que, en el trabajo, es el cuerpo -la vida, la piel- del trabajador el que está comprometido: a partir de entonces nos preocuparemos de asegurar mejor la seguridad física (seguridad en el trabajo). A continuación, tomaremos conciencia de que, al comprometer su cuerpo, es toda la persona del trabajador la que está en juego: progresivamente cuidaremos de garantizar la seguridad de su existencia más allá del mero tiempo de trabajo (seguridad mediante el trabajo). En definitiva, nos daremos cuenta de que mediante el trabajo lo que gana el trabajador es una identidad (entendida esta vez como ipseidad, es decir, una libertad en transformación); queremos decir, un lugar en la sociedad, una utilidad y en consecuencia una dignidad -para ser exhaustivos, un estatus, un conjunto de derechos y de obligaciones basado en un empleo estable (estatus de funcionario, contrato de duración indeterminada del trabajador). Más aun que la seguridad, el trabajo así repersonificado confiere al trabajador un "estado" generador de la pertenencia a una comunidad. Como observa 
A. Supiot, "el desarrollo del Derecho social ha provocado de esta forma un vuelta total del rol jugado por el contrato: de ser la expresión inicial de una concepción puramente individual de la relación de trabajo, el contrato se ha convertido, con el paso de los años, en el sésamo que permite acceder a un Derecho de los trabajadores definido colectivamente" ${ }^{64}$. Habiendo dejado de depender de los azares del acto jurídico puntual que representa el contrato, el trabajador se beneficia a partir de entonces de la protección continua que viene implicada por el disfrute de un estatus. Liberado de la tutela de las voluntades individuales, se trata, a partir de ese momento, de un sistema institucional acompañado de protecciones colectivas.

Si por entonces la forma contractual no ha desaparecido (queda todavía el acto-condición de la relación salarial que activa la aplicación del estatus), su supervivencia no ha tenido lugar mas que en la medida en que ha tenido éxito integrando el dispositivo legal que asegura al trabajador el estatus protector del que acabamos de hablar ${ }^{65}$. El orden público social impuesto por la fuerza pública no es, por lo demás, el único a quien esto concierne: las convenciones colectivas, los usos y la jurisprudencia contribuyen de esta forma a darle cuerpo. En este sentido, por ejemplo, pueden citarse las decisiones de la cámara social de la Corte de casación que han extraído de forma pretoriana una obligación de reclasificación del asalariado en caso de despido económico. En una sentencia de 25 de febrero de 1992, la alta jurisdicción ha juzgado "que el empleador, obligado a ejecutar de buena fe el contrato de trabajo, tiene el deber de asegurar la adaptación de los salarios a la evolución de sus empleos" $"$. Precisando esta jurisprudencia la cámara social ha juzgado, en una sentencia de 8 de Abril de 1992, que "en el marco de su obligación de reclasificación dentro de la empresa, el empleador debe, en caso de supresión o de transformación del empleo, proponer a los asalariados afectados los empleos disponibles de la misma categoría o, en su defecto, de categoría inferior, incluso si fuera esto necesario mediante modificación sustancial de los contratos de trabajo" "67. Imponiendo así al empleador adaptar eficazmente el contrato, ¿puede el juez expresar mejor su cuidado que teniendo en cuenta, en el tiempo de una historia evolutiva, la persona de los trabajadores?

Cierto es que hoy, como sabemos, esta evolución está comprometida por la flexibilización y la desreglamentación consecutivas en la mundialización

${ }^{64}$ Ibidem, pág. 89. Las líneas precedentes son una síntesis sumaria de las tesis defendidas por A. Supiot en las páginas 13 a 110 del trabajo citado.

${ }^{65}$ A. Supiot, op. cit., pág. 30.

${ }^{66}$ D., 1992, pág. 390, véase M. Defossez.

${ }^{67}$ J.C.P., 1992, éd. E, II, pág. 360, nota J. Savatier. 
de la economía. Se multiplican los signos en regresión hacia empleos cada vez más precarios y atípicos que traducen una cierta desinstitucionalización del estatus del asalariado. Es significativo que R. Castel hable en relación con esto de "desafiliación" para referirse a esta precarización de la condición salarial cuya "exclusión" es, en su extremo, el último indicio ${ }^{68}$. Si estas transformaciónes se confirmaran, nos encontrariamos con que, de nuevo, se persentaría amenazante el espectro de una cierta violencia contractual: el tiempo devorando a sus obras amenazaría.

\section{Tres intentos de interpretación}

Ricoeur decía "que el símbolo nos hace pensar". Podemos decir lo mismo de narraciones tales como la de Fausto y Shylock: en efecto, ahí encontramos materia para la reflexión, algo como una intuición espontánea de los problemas a los cuales conduce una cierta lógica contractual. Confirmadas por los análisis de Derecho positivo, estas intuiciones pueden ahora ser conceptualizadas con la ayuda de aproximaciones más teóricas. Son los recursos provenientes de la teoría socio-jurídica de los contratos, después los de la teoría pragmática de la acción y, en fin, los de la teoría general del Derecho, los que iremos invocando sucesivamente.

La aproximación socio-jurídica trata de abrir el estudio del contrato reemplazándolo dentro de un contexto económico y social global, algo que no deja de integrar sus prescripciones y su temporalidad en una normatividad y un espacio-tiempo más largos y más diversificados. El trabajo reciente de Jean-Guy Belley, Le contrat entre droit, économie et société ${ }^{69}$, puede ser considerado como un modelo de este tipo de análisis. Inspirado el mismo por la "teoría relacional del contrato" del americano I.R. MacNeil ${ }^{70}$, Belley se libra al estudio sistemático de la práctica contractual de la sociedad americana Alcan, gigante del aluminio, que opera en Québec. El desplazamiento del tipo de estudio que propone esta clase de análisis que pasa del contrato como concepto jurídico al contrato como hecho social, y el interés que lleva a las prácticas contractuales más allá de las meras reglas de Derecho, conduce a denunciar el reduccionismo del análisis jurídico clásico de los acuerdos, que infravalora sistemáticamente el aspecto organizativo de las empresas, la diversidad de los órdenes jurídicos que sus acuerdos integran y el tiempo contínuo dentro del cual conciben inscribir sus relaciones de negocios.

\footnotetext{
${ }^{68}$ R. Castel, Les métamorphoses de la question sociale, Paris, Fayard, 1995, pág. 411 y ss.

${ }^{69}$ Cowansville (Québec, ediciones Y. Blais, (1998).

${ }^{70}$ I.R. MacNeil, The New Social Contract. An Inquiry into Modern Contractual Relations, New Haven, Yale University Press, 1980.
} 
Partiendo de la distinción entre "contrato predominantemente transaccional" (la venta) y "contrato predominantemente relacional" (el contrato de trabajo), Belley señala, siguiendo a MacNeil, la importancia creciente de la dimensión relacional de los intercambios. No se trata de que los contratos transaccionales desaparezcan, pero la práctica muestra que son muy frecuentemente integrados en el marco de acuerdos de tipo relacional en las que se definen las políticas que la empresa concibe llevar a cabo a largo plazo tanto en relación con sus clientes y sus proveedores como en relación con sus empleados y la región dónde ejerce sus actividades ${ }^{71}$.

Cada vez que se intensifica y se prolonga la cooperación de las partes, las normas y los valores típicamente relacionales prevalecen sobre los imperativos específicamente transaccionales: la exigencia de un beneficio mutuo, la flexibilidad, el deber de buscar la preservación del futuro de la relación tienen, entonces, más importancia que la conformidad en la planificación inicial. "La relación global de las partes, las exigencias concretas de su cooperación, la solidaridad objetiva dentro de la cual les coloca su relación de cambio hacen entonces de contrapeso a las pretensiones de aquel a quien le gustaría aferrarse a la letra del contrato o a la única proyección inicial del cambio"72.

Dentro de estas condiciones, la fuente de las proyecciones para el futuro perseguidas por la empresa no se sitúa ya más exclusivamente en el intercambio de consentimientos y en la autonomía de las voluntades, sino más bien en un entramado complejo de normas, de usos, de prácticas, de valores y de exigencias inscritas en espacios diferenciados, y a las cuales sólo el concepto de "internormatividad" puede hacer justicia. Es así como los contratos de Alcan hacen surgir no menos de cinco "estratos" (u "órdenes") jurídicos diferentes ${ }^{73}$ : el orden jurídico estático del que es preciso respetar las prescripciones imperativas, la lógica reglamentaria "burocrática" interna a la empresa que conduce a una estandarización muy constringente de sus operaciones, la normalización técnica de sus políticas de aprovisionamiento que se analizan como el resultado de una planificación macro-económica en relación con la mundialización de la economía, las alianzas de tipo jurídico-político suscritas con la región y que traducen la voluntad de cooperar en el largo plazo para el progreso de los dos socios y, en fin, las relaciones individualizadas donde predominan las exigencias "morales" de la asociación, de la confianza y de la lealtad, y en las que se da buena cuenta del modelo de "contrato-estatus" del que hablaba Max Weber ${ }^{74}$. Entre el respe-

\footnotetext{
${ }^{71}$ J.G. Belley, Le contrat entre droit, économie et société, op. cit., pág. 302.

${ }^{72}$ Ibidem, pág. 304.

${ }^{73} \mathrm{Ibidem}$, pág. 205 y ss.

${ }^{74}$ Ibidem, pág. 223.
} 
to de los "intentos legítimos" de una de las partes, inherentes a este "contrato-estatus", la puesta en marcha rutinaria de las prescripciones burocráticas internas, la integración de los objetivos políticos de la región, el respeto por las reglamentaciones estáticas y la conformación a las exigencias de una planificación económica, nos damos cuenta de en qué medida los contratos suscritos por Alcan deben operar, día a día, una conciliación dinámica entre los objetivos diversificados que desbordan por mucho la letra del contrato y el tiempo de los compromisos puntuales que ha concluido. En este modelo interactivo y complejo, la práctica contractual actúa como un instrumento suave para la dirección de las conductas y susceptible siempre de ajustes y revisiones. Lejos de encerrar a las partes en un collar rígido, el contrato se convierte en un instrumento de una política "reflexiva" que aprende de sus propios errores al tiempo que de sus éxitos y va integrando sus resultados en sus previsiones, con el fin de conciliar en la mejor medida posible las exigencias múltiples y a veces contradictorias (las del mercado y las de la ciudadanía, p.ej.) a las cuales la empresa ha de hacer frente.

El tiempo "relacional" que se desprende de esas prácticas es a la vez continuo y más evolutivo que el tiempo "transaccional" del intercambio puntual. Es un tiempo institucional, podríamos decir, reenviando de esta forma a las anticipaciones de Maurice Hauriou que hace varios decenios ya señalaba la multiplicación de los acuerdos que siendo contractuales en su origen se convertían progresivamente en institucionales ${ }^{75}$. El caso de las sociedades comerciales, cuya naturaleza jurídica es al menos tan estatutaria como contractual, es una ilustración significativa de esto. En tales hipótesis, señalaba Hauriou, un elemento de solidaridad se desarrolla entre las partes, haciendo que sus desacuerdos pronto no surjan más de la sola justicia "conmutativa" propia del toma y da contractual; se les presentarán riesgos imprevisibles, se tratará a partir de entonces de que el juez los reparta según la lógica "distributiva" adecuada a la institución ${ }^{76}$. Veámoslo: los análisis "relacionales" (MacNeil, Belley) e "institucionales" (Hauriou) convergen; en un buen número de casos, el contrato posee un tiempo más suave, más complejo y más solidario que éste, rígido y fijo, que se aferra a su letra y a la intención inicial que se supone que ha de traducir.

${ }^{75}$ Cfr. J.-A. Broderick, "La notion d' 'institution' de Maurice Hauriou dans ses rapports avec le contrat en droit positif francais" en Archives de philosophie du Droit, 1968, pág. 143 y s.; M. Hauriou, "L'imprévision et les contratas dominés par les institutions sociales", en Cahiers de la Nouvelle Journée, 1933, vol. 23, págs. 129 y ss.

${ }^{76}$ M. Hauriou, op.cit., pág. 138 y ss. 
La teoría pragmática de la acción que ilustra, por ejemplo, la obra de Pierre Livet: La communauté virtuelle. Action et coopération ${ }^{77}$ confirma estas enseñanzas. Escribe P. Livet que "hemos abandonado la idea de una acción definida a partir de su intención, para estudiar una acción cuyo sentido está forjado a lo largo del camino, según las correcciones de las trayectorias que los errores y los imprevistos sugieren"78. De este abandono -típico de una aproximación "pragmática"- se deducirá un triple descentramiento en relación con la teoría clásica de la esencia "semántica". Cuando buscamos el sentido de la acción, más que concentrarnos en la iniciativa del emisor del mensaje (¿qué ha querido decir o hacer?), atenderemos a la manera en que sus actos y sus comportamientos son interpretados por el receptor (¿qué expectativas legítimas han suscitado en éste?) ${ }^{79}$. Más que aferrarnos únicamente al acuerdo explícito, tendremos en cuenta igualmente su "background” implícito (¿Cómo fue preparado? ¿Cómo se ejecuta? ¿Qué normativa subyacente moviliza?). Más que aferrarse a una concepción rígida del contrato cristalizado en forma de archivo, nos aferraremos a una concepción dinámica de la colaboración, siempre susceptible de revisión y de ajuste.

Midamos las objeciones que desde esta aproximación pueden serle dirigidas a la perspectiva clásica. Ésta, lo recordamos, no ve el contrato mas que en "la intención común y real" de las partes. Una intención que se supone que debe ser irrevocablemente fijada en el instante mágico de la formación del contrato. Así, la vida entera del acuerdo, desde su negociación hasta la reglamentación ulterior de sus incidentes de ejecución, es encerrada en un tiempo puramente abstracto y ficticio, sustraído a la puesta en funcionamiento concreto que recibe en el tiempo de la realidad.

El contrato era considerado "perfecto", lo recordamos, desde el momento en que una oferta completa había sido aceptada pura y simplemente: en la medida en que las voluntades no estén "viciadas", el acuerdo se cristaliza por el reencuentro de dos voluntades concordantes. Pero, precisamente, ¿no nos enseñan hoy las ciencias cognitivas que las intenciones reales de cada

${ }^{77}$ P. Livet, La communauté virtuelle. Action et cooperation, Paris, editions de l'Eclat, 1994; para una transposición de la tesis de este trabajo al dominio de la cooperación contractual, cfr. B. Frydman, Le droit des contrats á la lumiere de la philosophie de l'action: indécidabilité, coopération et revisión, por aparecer.

${ }^{78}$ P. Livet, op. cit., pág. 159.

${ }^{79}$ Cfr. Concretamente J. Ghestin, La notion de contrat, op. cit., pág. 151: "No es el valor que el interesado ha entendido que le concedía a su comportamiento el que debe ser tomado en consideración, sino el significado objetivo que los terceros, especialmente el co-contratante, han podido, legítimamente, atribuirle. Todo comportamiento, activo y pasivo, puede de esta forma manifestar la voluntad de su autor, desde el momento en que es usual reconocerle tal significación, o igualmente cuando ésta resulte normalmente de un determinado tipo de circunstancias. Esta solución viene impuesta por el principio de seguridad jurídica”. 
uno son, decididamente, poco "demostrables" $"$ "Q ¿Qué decir entonces de las pretendidas intenciones "comunes"? ¿Qué decir, sobre todo, de las intenciones comunes que se supone que se han fijado definitivamente en el instante de la conclusión del contrato, como si la práctica ulterior no contribuyera a hacer evolucionar el sentido de éste?

Más que de cristalizar una improbable voluntad fijada en el preciso instante del acuerdo inicial, ¿no se trata desde ese momento de desplegar, como trata de demostrarlo la práctica jurisprudencial, un espacio para la deliberación y un campo de prácticas que, tanto antes como después del acuerdo, contribuye a precisar el sentido de éste -un sentido finalizado por el espíritu de colaboración que es la regla fundamental de la institución contractual?

Hemos visto que es desde este espíritu desde el que hoy se desarrolla un derecho "precontractual" que enmarca las negociaciones previas al acuerdo: se dispone a cargo de las partes obligaciones de información y de diligencia; se trata de que ellas colaboren con el fin de conseguir la conclusión de un contrato que tenga validez dentro de un plazo razonable. Es el mismo espíritu que debería, según una doctrina y una jurisprudencia en vía de formación, dirigir igualmente la resolución de las dificultades ulteriores de la interpretación y de la ejecución del contrato. O bien la referencia a la "buena fe" o a las "expectativas legítimas" de la contraparte ${ }^{81}$ permitirá llenar las lagunas del acuerdo, obligando a las partes a aquellas implicaciones derivadas de las obligaciones según sea su naturaleza (art. 1135 del Código civil), como la buena fe se opondrá al "abuso" por una de las partes de su derecho cuando trate de conseguir una ventaja desproporcionada causando perjuicio a la parte co-contratante, o bien, finalmente, autorizará la renegociación del acuerdo en caso de que sobrevengan circunstancias excepcionales.

¿No nos encontramos de nuevo aquí con lo que denominábamos el tiempo del "imperfecto"? La relativa incertidumbre de las intenciones iniciales, la esencial incompletitud de las palabras y de los actos, lejos de conducir a la imperfección del acuerdo, justifican tanto una atención más grande a su ejecución concreta, como una obligación evolutiva de colaboración que reafirme las promesas.

La teoría general del Derecho ofrece una tercera aclaración de los fenómenos estudiados. Así, como debe ser, tomando de la altura y extendiendo el propósito a la producción de normas en general, la teoría general del Derecho ve en las evoluciones estudiadas el deslizamiento desde una concepción positivista del tiempo jurídico a una concepción que, a falta de algo mejor,

\footnotetext{
${ }^{80}$ P. Livet, Op.cit., págs. 70-89.

${ }^{81}$ Sobre esta noción, cfr. X. Dieux, Le respect dî aux anticipations légitimes d'autrui. Essai sur la genèse d' un principe général de droit, Paris-Bruxelles, LGDJ-Bruylant, 1995.
} 
llamaremos "post-positivista" (no hablo de "iusnaturalismo" para evitar la oposición dicotómica y estéril entre Derecho natural y Derecho positivo).

El tiempo positivista se concentra en los actos jurídicos, expresiones de la voluntad normativa de las personas privadas o de la soberanía del poder público. Tales actos, fruto de una especie de generación espontánea y a los que se ha prometido una vida eterna, se benefician instantáneamente -como hemos visto- de la fuerza jurídica y permanecen en vigor hasta que otra norma, también "espontánea", los abroga o los sustituye. Tanto la teoría civilista del contrato como la teoría publicista de la ley tienen la marca de tal instantaneidad. Se deduce de esto un modelo sincopado del orden jurídico reducido a una sucesión de actos y de normas sin un vínculo inteligible. Este modelo está, en efecto, desprovisto de un pensamiento y de una deontología de la relación entre reglas; los principios de su formación permanecen fuera del campo jurídico, con la excepción de la regulación puramente procesal de su sucesión.

Aislado de esta forma de los movimientos de opinión y de presión sociales que se ejercen sobre las reglas, sobre sus prácticas y sus interpretaciones, este modelo positivista se propone garantizar la seguridad jurídica. Pero, además, como se trata con frecuencia exclusivamente de la seguridad del más fuerte, esta seguridad tiene toda la vulnerabilidad del roble que resiste hasta el día en que, a falta de flexibilidad, se parte en dos.

Este tiempo positivista cede progresivamente el paso hoy a una temporalidad más "metamórfica" -queremos decir un tiempo de la transformación progresiva, el tiempo de las identidades que saben convertirse en otras sin dejar po ello de ser ellas mismas. Estas entidades no se interpretan más exclusivamente como "actos", sino también como "instituciones", que son encadenamientos de actos, de procesos en curso, de procedimientos evolutivos. La dialéctica que ellas ponen en acción es, a partir de ahora, menos esa, discontinua, de la instantanidad y de la intangibilidad, que la otra, mucho más continua, de lo instituido y el instituyente: las voluntades toman cuerpo en las formas instituidas que las fuerzas instituyentes transforman, sin embargo, a lo largo del tiempo. El modelo se enriquece de esta forma con una teoría y una deontología de las transformaciones normativas que dejan de hacer surgir únicamente reglas procesales. Lo hemos visto: al encuentro del estatismo de la convención-ley hoy se hace valer una regulación del momento que precede (negociación) y del que sigue al acuerdo (ejecución). También en el Derecho público se reintroduce la idea de una continuidad jurídica del Estado, de la nación, y de "las ideas del Derecho", generadora de un Derecho pre- y transconstitucional. Y, desde el punto de vista de la seguridad jurídica, lo que este modelo pierde en previsibilidad -dada la posibilidad siempre abierta de un ajuste de la convención-, lo gana en capacidad 
de previsión de adaptación -su seguridad, podríamos decir, es la del junco que se dobla pero no se rompe. Subrayaremos en fin que, si el modelo positivista valora las voluntades al inscribirse dentro de una perspectiva monista y jerarquizada del sistema jurídico, el modelo post-positivista, por el contrario, presupone que el Derecho se articula en una red, es decir, presupone la pluralidad y el anudamiento de las fuentes normativas entre las que se requiere que se desarrolle una colaboración.

De esta forma, paso a paso, la práctica jurídica del contrato es la prueba de un tiempo deneguentropía: un tiempo creador en cuanto que imperfecto- un tiempo abierto y plural que no trae el otro hacia sí, ni el yo hacia sí mismo. Pero todo eso estaba, sin duda, ya contenido, y de una forma muy sugestiva, en la historia de Shylock y en el mito de Fausto.

(Trad. Victoria Roca) 